

\section{Carbon dioxide efficiency of terrestrial enhanced}

\section{2 weathering}

$4{ }^{1}$ University of Hamburg, KlimaCampus, Institute for Geology, Bundesstraße 55, 20146

Hamburg, Germany

62 University of Oxford, Department of Earth Sciences, South Parks Road, Oxford OX1 3AN,

$8 \quad$ * Email: nils_sci@moosdorf.de, tel: +49 40428386683

9 Keywords: Geoengineering, Enhanced weathering, CO2, carbon management

\section{Abstract}

12 Terrestrial enhanced weathering of ultramafic silicate rocks, the spreading of rock flour to

13 enhance natural weathering rates, has been suggested as part of a strategy to reduce global

14 atmospheric $\mathrm{CO}_{2}$ levels. Here, we assess the net $\mathrm{CO}_{2}$ removal of terrestrial enhanced weathering,

15 by budgeting potential $\mathrm{CO}_{2}$ sequestration against the associated $\mathrm{CO}_{2}$ emissions. We combine

16 global spatial datasets of potential source rocks, transport networks and application areas with 
$17 \mathrm{CO}_{2}$ emissions associated with source rock processing in an optimistic and a pessimistic 18 scenario.

19 Terrestrial enhanced weathering consumes more $\mathrm{CO}_{2}$ than it emits for mining, comminution,

20 transport, and application in most locations. The $\mathrm{CO}_{2}$-efficiency is dominated by the choice of

21 source rocks and material comminution. $\mathrm{CO}_{2}$ emissions from transport have a small effect on the

22 overall budget (on average $0.5-3 \%$ of potentially sequestered $\mathrm{CO}_{2}$ ) and the emissions of material

23 mining and application are negligible. After all emissions, 0.5-1.0 t $\mathrm{CO}_{2}$ can still be sequestered

24 on average per tonne of rock. However, very large amounts of rock would be needed to control

25 or reduce the atmospheric $\mathrm{CO}_{2}$ concentrations substantially with enhanced weathering. Before

26 enhanced weathering could be applied at large scales, more research is needed to assess

27 weathering rates, potential side effects, social acceptability, and mechanisms of governance.

28 TOC Art

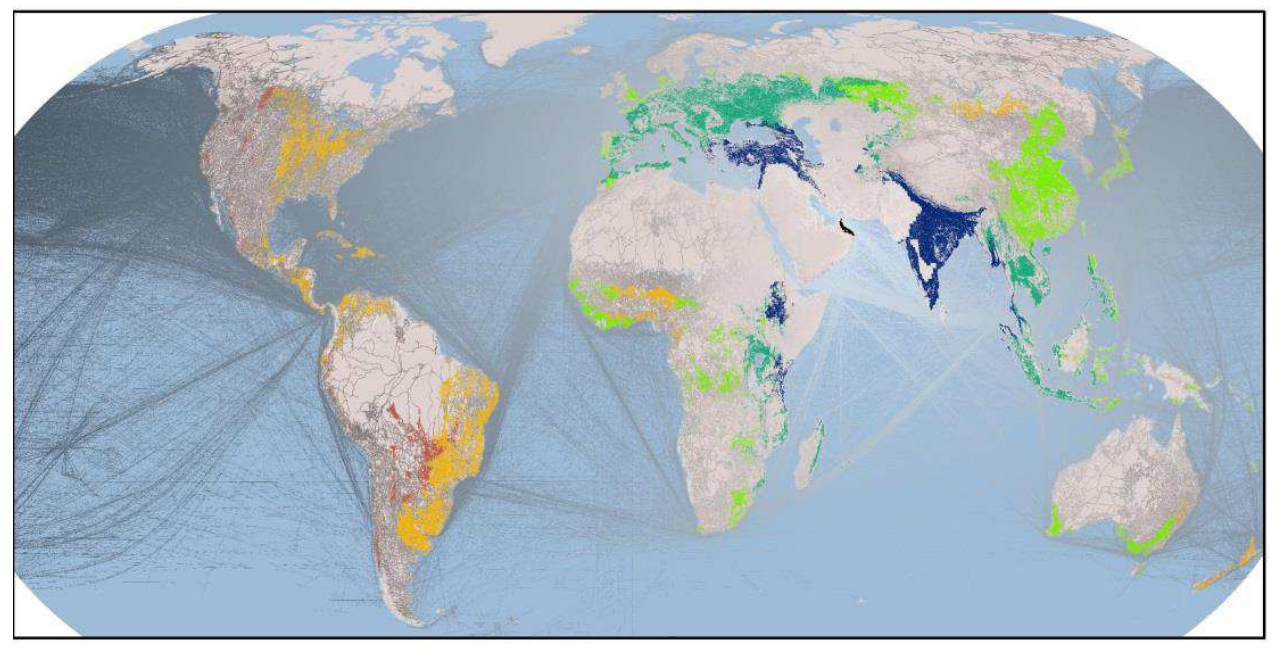

29

30

\section{Introduction}


32 Rising levels of atmospheric $\mathrm{CO}_{2}$ may cause substantial challenges for human society.

33 Stagnation in efforts to cut anthropogenic $\mathrm{CO}_{2}$ emissions has led to the proposal of technological

34 solutions for capturing and storing atmospheric $\mathrm{CO}_{2}{ }^{1-4}$. Terrestrial enhanced weathering was

35 suggested as one of these solutions ${ }^{5-7}$. The term "terrestrial enhanced weathering" is commonly

36 used for the application of ultramafic silicate rock powder to suitable application areas to

37 increase natural chemical weathering rates ${ }^{6-10}$.

38 Natural chemical silicate rock weathering is a major geological sink of atmospheric $\mathrm{CO}_{2}{ }^{11-13}$.

39 The release of cations during mineral weathering binds dissolved $\mathrm{CO}_{2}$ to form bicarbonate and

40 carbonate ions, which are then transported to the ocean. Annually, natural chemical silicate

41 weathering consumes about 0.86 to $1.06 \mathrm{Gt}$ of atmospheric $\mathrm{CO}_{2}{ }^{14-16}$. Chemical weathering of

42 forsterite is exemplary of the process (Eq. 1):

43 Equation 1: $\mathrm{Mg}_{2} \mathrm{SiO}_{4}+4 \mathrm{CO}_{2}+4 \mathrm{H}_{2} \mathrm{O}=>2 \mathrm{Mg}_{2}++4 \mathrm{HCO}_{3}{ }^{-}+\mathrm{H}_{4} \mathrm{SiO}_{4}$

44 Theoretically, based on stoichiometry and mass, the weathering of a $4 \mathrm{~mm}$ thick layer of

45 forsterite (Mg-olivine) spread over the entire terrestrial land mass could consume all atmospheric

$46 \mathrm{CO}_{2}{ }^{6}$. In practice, there are limits to sequestration potential, e.g. due to saturation effects ${ }^{17}$. Silica

47 saturation, for example, could limit the $\mathrm{CO}_{2}$ sequestration in humid tropical regions to $3.7 \mathrm{Gt}$

$48 \mathrm{CO}_{2} \mathrm{a}^{-1}{ }^{17}$, although an abiotic limitation by forsterite saturation may substantially reduce that

49 value $^{7}$. Furthermore, carbonate minerals may precipitate which would liberate up to half of the

50 sequestered $\mathrm{CO}_{2}$ to the atmosphere[manning ref, manning and renforth], but is unclear if the

51 weathering rates are sufficient to supersaturate solutions with respect to carbonate phases. If

52 carbonates precipitate, it is likely the containing $\mathrm{CO}_{2}$ will be sequestered for millions of years ${ }^{2}$,

$53{ }^{11}$. All of the key technologies required for terrestrial enhanced weathering are mature and

54 already used on regional scale for fertilization or $\mathrm{pH}$-management of agricultural and forest soils.

55 However, the industry and associated environmental impact of up-scaling this technology require 
56 consideration. Possible side effects of terrestrial enhanced weathering on e.g. river $\mathrm{pH}$ and 57 alkalinity ${ }^{17}$, or release of metals ${ }^{10,18}$ are related to the source rock composition as well as the 58 deployment extent and method. In addition, the availability of suitable land may be a major

59 limiting factor ${ }^{4}$, and the infrastructure requirements of transporting large volumes of rock could 60 inherently limit the available application area.

61 Ultramafic igneous rocks have the largest carbon sequestration potential by mass and fastest 62 dissolution rates of silicate rocks, and are thus likely to be the most applicable for terrestrial 63 enhanced weathering ${ }^{19-22}$. Several studies have already investigated their carbonation potential at 64 elevated temperatures and under elevated $\mathrm{pCO}_{2}$ in reactors ${ }^{23-25}$, which can be referred to as 65 "accelerated weathering", although "mineral carbonation" is used here to delineate. For mineral 66 carbonation, formalized life cycle studies exist $^{26}$. The capital investment required for mineral

67 carbonation (e.g. for creating a large reactor), may limit deployment [REF]. The terrestrial 68 enhanced weathering assessed here conceptually uses soil as a 'reactor', potentially negating 69 some of the capital expenditure for mineral carbonation. However, these technologies are not 70 necessarily mutually exclusive, and it may be that mineral carbonation is applicable alongside, or 71 preponderate to, terrestrial enhanced weathering. .

72 As a first step to investigate the feasibility of the method at the global scale, a basic carbon 73 budget of terrestrial enhanced weathering has been performed to identify key areas of uncertainty 74 for future research. Expanding on the study of Renforth ${ }^{9}$, which focused on the United 75 Kingdom, this study globally constrains the net- $\mathrm{CO}_{2}$-efficiency of terrestrial enhanced 76 weathering by applying optimistic and pessimistic scenarios of a spatially explicit carbon budget. 77 Rock properties, mining, comminution, transport, and application are included in the analysis 78 presented here. 


\section{Data and methods}

80 Spatial datasets representing source rocks, transport pathways and potential application areas

81 were combined with associated $\mathrm{CO}_{2}$ emissions (into the atmosphere) and sequestration (from the

82 atmosphere) to develop a spatially explicit $\mathrm{CO}_{2}$ budget of terrestrial enhanced weathering, and

83 identify its net efficiency on areas suitable for its application. This does not account for a

84 potential increase in biomass or crop production due to the release of geogenic nutrients during

85 the dissolution process ${ }^{7}$. The main $\mathrm{CO}_{2}$ emissions associated with terrestrial enhanced

86 weathering are generated by mining, crushing/milling, transport and spreading of the rock

87 material, for which a pessimistic and an optimistic scenario were defined (Table 1). The

88 technically simple process of spreading rock flour on agricultural areas simplifies the $\mathrm{CO}_{2}$

89 budget compared to the technically more complex accelerated weathering in reactors, where $\mathrm{CO}_{2}$

90 budgets in addition to the here assessed aspects have to account for chemical conversion,

91 beneficial reuse, transport of used minerals and disposal ${ }^{26}$. The $\mathrm{CO}_{2}$ budget of enhanced

92 weathering is calculated after Equation 2:

93 Equation 2: $\Delta \mathrm{CO}_{2}=$ Potential $\mathrm{CO}_{2}$ sequestration (based on source rock properties) $-\mathrm{CO}_{2}$

94 emissions (Mining + Comminution + Transport + Application )

$95 \Delta \mathrm{CO}_{2}$ will later be referred to " $\mathrm{CO}_{2}$ available for sequestration", which implies that this is the

96 amount of $\mathrm{CO}_{2}$ which could effectively sequestered (without giving a statement of the time that

97 takes) after subtracting the emissions from the maximum potential sequestration. The datasets

98 representing the individual parts of the budget are provided in Table 1 and illustrated in Figure 1.

99 All datasets were combined in a global GIS and resampled to a grid resolution of $1 \times 1 \mathrm{~km}$ (all

100 GIS functionality implemented in the software ArcGIS 10 by ESRI $\left.{ }^{\circledR}\right)$. 
Table 1: Factors affecting the $\mathrm{CO}_{2}$ budget of terrestrial enhanced weathering and their assumed $\mathrm{CO}_{2}$ emissions and sequestration. In the budget, negative values indicate $\mathrm{CO}_{2}$ emissions (into the atmosphere); positive values indicate $\mathrm{CO}_{2}$ sequestration (from the atmosphere).

\begin{tabular}{|c|c|c|c|c|c|c|c|c|}
\hline Theme & $\begin{array}{l}\text { Spatial } \\
\text { Data } \\
\text { Reference }\end{array}$ & $\begin{array}{l}\mathrm{CO}_{2} \\
\text { budget } \\
\text { reference }\end{array}$ & $\begin{array}{l}\text { Condition } \\
\text { optimistic }\end{array}$ & $\begin{array}{l}\text { Condition } \\
\text { pessimistic }\end{array}$ & $\begin{array}{l}\text { Value } \\
\text { optimistic }\end{array}$ & $\begin{array}{l}\text { Value } \\
\text { pessimistic }\end{array}$ & Unit $^{\mathrm{a})}$ & Comments \\
\hline $\begin{array}{l}\text { Source } \\
\text { material }\end{array}$ & 27 & & Ultramafic rocks & Ultramafic rocks & 736 & 736 & $\begin{array}{l}10^{3} \\
\mathrm{~km}^{2}\end{array}$ & \\
\hline $\begin{array}{l}\text { Potential } \\
\text { maximum } \mathrm{CO}_{2} \\
\text { sequestration }\end{array}$ & & 9 & $\begin{array}{l}\text { Upper limit for } \\
\text { ultramafic rocks } \\
\text { in Fig. } 1 \text { of the } \\
\text { reference }\end{array}$ & $\begin{array}{l}\text { Lower limit for } \\
\text { ultramafic rocks } \\
\text { in Fig. } 1 \text { of the } \\
\text { reference }\end{array}$ & 1.10 & 0.80 & $\begin{array}{l}\mathrm{tCO}_{2} \mathrm{CO} \\
\mathrm{t}^{-1}\end{array}$ & \\
\hline Mining & & 8 & $\begin{array}{l}\text { Estimated energy } \\
\text { need (18.8 } \mathrm{MJ} \mathrm{t}^{-1} \\
\text { rock) times } \mathrm{CO}_{2} \\
\text { emission per } \mathrm{MJ} \\
\text { provided by } 9\end{array}$ & $\begin{array}{l}\text { Estimated energy } \\
\text { need (18.8 } \mathrm{MJ} \mathrm{t}^{-1} \\
\text { rock) times } \mathrm{CO}_{2} \\
\text { emission per } \mathrm{MJ} \\
\text { provided by } 9\end{array}$ & -0.007 & -0.007 & $\begin{array}{l}\mathrm{tCO}_{2} \\
\mathrm{t}^{-1}\end{array}$ & \\
\hline $\begin{array}{l}\text { Crushing / } \\
\text { milling }\end{array}$ & & 9 & $\begin{array}{l}0.6 \mathrm{GJ} / \mathrm{t} \text { energy } \\
\text { demand (see } \\
\text { supplemental }\end{array}$ & $\begin{array}{l}2 \text { GJ / t energy } \\
\text { demand (see } \\
\text { supplemental }\end{array}$ & -0.07 & -0.22 & $\begin{array}{l}\mathrm{tCO}_{2} \\
\mathrm{t}^{-1}\end{array}$ & \\
\hline
\end{tabular}




\begin{tabular}{|c|c|c|c|c|c|c|c|c|}
\hline & & & information) & information) & & & & \\
\hline Road & 28 & 29 & Lower estimate & Upper estimate & -59 & -109 & $\begin{array}{l}\mathrm{g} \mathrm{CO}_{2} \\
\mathrm{~km}^{-1} \\
\mathrm{t}^{-1}\end{array}$ & \\
\hline Railroad & 28 & 29 & Lower estimate & Upper estimate & -7 & -26 & $\begin{array}{l}\mathrm{g} \mathrm{CO}_{2} \\
\mathrm{~km}^{-1} \\
\mathrm{t}^{-1}\end{array}$ & \\
\hline Trail & 28 & 29 & Lower estimate & Upper estimate & -59 & -109 & $\begin{array}{l}\mathrm{g} \mathrm{CO}_{2} \\
\mathrm{~km}^{-1} \\
\mathrm{t}^{-1}\end{array}$ & $\begin{array}{lr}\text { Values } & \text { taken } \\
\text { from } & \text { class } \\
\text { "road" } & \end{array}$ \\
\hline Rivers & 30 & 29 & Lower estimate & Upper estimate & -28 & -35 & $\begin{array}{l}\mathrm{g} \mathrm{CO}_{2} \\
\mathrm{~km}^{-1} \\
\mathrm{t}^{-1}\end{array}$ & $\begin{array}{l}\text { Used major } \\
\text { world rivers }\end{array}$ \\
\hline $\begin{array}{l}5 \mathrm{~km} \text { buffer } \\
\text { around roads, } \\
\text { railroads, trails } \\
\text { and rivers }\end{array}$ & $\begin{array}{l}\text { Self- } \\
\text { defined }\end{array}$ & 29 & Lower estimate & Upper estimate & -59 & -109 & $\begin{array}{l}\mathrm{g} \mathrm{CO}_{2} \\
\mathrm{~km}^{-1} \\
\mathrm{t}^{-1}\end{array}$ & $\begin{array}{lr}\text { Values } & \text { taken } \\
\text { from } & \text { class } \\
\text { "road" } & \end{array}$ \\
\hline Shipping lines & 31 & 29 & Lower estimate & Upper estimate & -5 & -20 & $\begin{array}{l}\mathrm{g} \mathrm{CO}_{2} \\
\mathrm{~km}^{-1} \\
\mathrm{t}^{-1}\end{array}$ & \\
\hline $\begin{array}{l}\text { Application } \\
\text { emissions }\end{array}$ & & 32 & $\begin{array}{l}1 \mathrm{t} \text { per ha, } 80 \text { ha } \\
\text { per field }\end{array}$ & $\begin{array}{l}3 \mathrm{t} \text { per ha, } 1 \text { ha } \\
\text { per field }\end{array}$ & -0.0011 & -0.004 & $\begin{array}{l}\mathrm{t} \mathrm{CO}_{2} \\
\mathrm{t}^{-1}\end{array}$ & $\begin{array}{l}\text { Using a factor } \\
\text { of } 2.6 \text { to } \\
\text { calculate } \mathrm{CO}_{2} \\
\text { emissions } \\
\text { from the }\end{array}$ \\
\hline
\end{tabular}




\begin{tabular}{|c|c|c|c|c|c|c|c|}
\hline & & & & & & & $\begin{array}{l}\text { reported diesel } \\
\text { volume. }\end{array}$ \\
\hline Arable land & 33,34 & $\begin{array}{l}\text { Upper estimate } \\
\text { of proportions on } \\
\text { cells, outside } \\
\text { polar or arid } \\
\text { climates. }\end{array}$ & $\begin{array}{l}\text { Lower estimate } \\
\text { of proportions on } \\
\text { cells, outside } \\
\text { polar or arid } \\
\text { climates. }\end{array}$ & 14.7 & 11.8 & $\begin{array}{l}10^{6} \\
\mathrm{~km}^{2}\end{array}$ & \\
\hline
\end{tabular}

103 a) $\mathrm{t}^{-1}$ refers to tons of rock. 

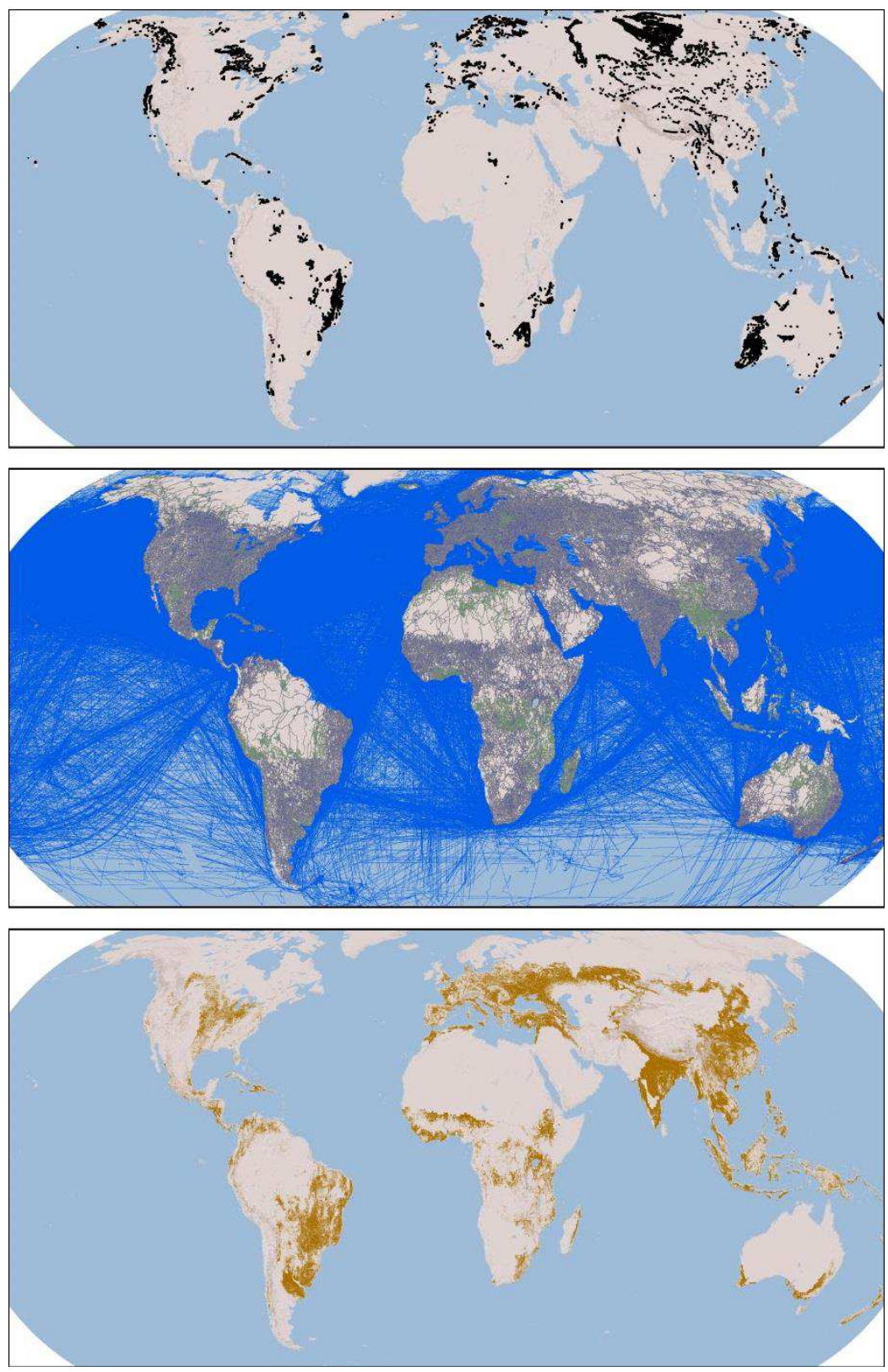

108 Figure 1: Spatial input data of the study. a) Source rock locations according to the GLiM (black,

109 area exaggerated for visibility, coverage of potential source rocks is not exhaustive), b) Transport

110 routes (colors indicate different modes of transport, but the grid is too fine to be resolved in the 111 image), c) Application area. 


\section{Material source rocks}

114 Ultramafic rocks suitable for terrestrial enhanced weathering are generally rich in the mineral

115 forsterite (the olivine $\mathrm{Mg}$-end member) which was previously recommended for this technique ${ }^{6}$,

116 35. The Global Lithological Map (GLiM) ${ }^{27}$ contains $736,000 \mathrm{~km}^{2}$ of rock units in which

117 ultramafic rocks occur (Figure 1) but does not identify all ultramafic rocks globally. The source

118 maps of the GLiM emphasize ultramafic rocks differently, and e.g. in Japan, Iceland or eastern

119 Africa, additional ultramafic rock occurrences are likely. The maximum potential $\mathrm{CO}_{2}$

120 sequestration per tonne of rock material is represented by upper (optimistic scenario) and lower

121 (pessimistic scenario) literature values of the $\mathrm{CO}_{2}$ sequestration of ultramafic rocks ${ }^{9}$. In the case

122 that the source rock consists of pure forsterite, the potential maximum $\mathrm{CO}_{2}$ sequestration (at

123 neutral $\mathrm{pH}$ ) would be even higher, namely $1.25 \mathrm{t} \mathrm{CO}_{2} \mathrm{t}^{-1}$, based on the stoichiometry of equation 1241.

\section{Material application areas}

126 Potential application areas need to 1) provide a suitable environment for chemical weathering

127 and 2) be accessible for terrestrial material spreading. Suitable environments are moist and

128 warm, based on the assumption that moisture is needed for a dissolution reaction and

129 temperature increases chemical weathering rates ${ }^{36}$. These conditions are here represented by

130 omitting areas from dry and very cold climate zones (Main classes "Arid climates" and "Polar

131 climates" 34 ) for application. Areas suitable for terrestrial spreading of rock powder are defined

132 by arable land $\operatorname{cover}^{33}$ (Figure 1). Arable land seems most suitable for application because it is

133 already intensively managed and spreading crushed rock would, notionally, require only limited

134 new infrastructure. The land cover data provide a proportion range to which each cell is covered 135 by arable land ${ }^{33}$. The upper (optimistic) and lower (pessimistic) ends of that range are used here 
136 (Table 1). Land cover data were converted from raster into polygon data using the "Raster to

137 Polygon" tool implemented in ArcGIS. This combines neighboring cells with the same attributes

138 into one polygon with a unique identifier. These were reconverted into raster cells with that

139 identifier to define individual agricultural areas and link them to the transport datasets.

140 Material extraction

141 Extraction and application require minimal amounts of energy, which are included in the

142 budget. The energy demand for surface extraction is $18.8 \mathrm{MJ} \mathrm{t}^{-1}{ }^{8}$, which was translated into $\mathrm{CO}_{2}$

143 emissions (Table 1).

144 Material comminution

145 Size reduction of rock is achieved in a number of steps including at least one instance of 146 crushing, followed by milling or grinding 9 . Crushing, required for particle size reduction to 1

$147 \mathrm{~mm}$ diameter, can be achieved with minimal energy input (5-10 $\left.\mathrm{MJ} \mathrm{t}^{-1}{ }^{9}\right)$. It is likely that 148 additional size reduction to $<100 \mu \mathrm{m}$ will be required, which necessitates grinding. The energy 149 required in this process is directly related to the surface area created ${ }^{8,9,23,37}$. We use a shrinking 150 core model (see supporting information) to calculate the initial particle diameter required to 151 achieve complete weathering within 1 year given a specific weathering rate. The grinding energy 152 to produce this particle size is then calculated. An optimistic (and pessimistic) log weathering 153 rate of -12 (and -18) $\mathrm{mol} \mathrm{m}^{-2} \mathrm{~s}^{-1}{ }^{9}$, was used to calculate a grinding energy of

$1540.6(2.0) \mathrm{GJ} \mathrm{t}^{-1}$, which emits $0.07(0.22) \mathrm{t} \mathrm{CO}_{2} \mathrm{t}^{-1}$ due to electrical energy use. As we have not 155 included a temporal dimension into our analysis, the weathering rates remain effectively constant 156 in the shrinking core model. The 6 orders of magnitude range in weathering rates between the 157 optimistic and pessimistic scenarios is indicative of the range of values between laboratory 158 determined kinetics of 'fresh' material and heavily weathered material in catchment scale 
159 studies. Few experimental data exist that investigate silicate minerals added to the environment.

160 As such, the treatment of kinetics for terrestrial enhanced weathering is highly uncertain.

$161 \quad$ Material transport

162 Rock material for terrestrial enhanced weathering could be transported on shipping routes

163 (oceans, certain rivers and channels), train lines and roads. Airfreight is disregarded here because

164 of its high associated $\mathrm{CO}_{2}$ emissions. This study combines various global datasets to generate a

165 routing raster from the source rock areas to the application areas. Shipping lanes are represented

166 by a dataset of known ship positions ${ }^{31}$. Each grid cell with at least one documented ship position

167 in the original data is considered a potential shipping lane. For river transport, 98 major rivers of

168 the world ${ }^{30}$, with an average length of $2660 \mathrm{~km}$ were included and assumed to be navigable. This

169 assumption was verified against available maps of navigable waterways. Only the upper reaches

170 of the rivers may be too small for ships to pass, but the resulting underestimation of transport

$171 \mathrm{CO}_{2}$ emissions should be very small, as $1000 \mathrm{~km}$ transportation on rivers emits only $0.03(0.07) \mathrm{t}$

$172 \mathrm{CO}_{2} \mathrm{t}^{-1}$ less than on roads, in the optimistic (pessimistic) scenario. Land transport routes were

173 derived from the VMAP0 dataset ${ }^{28}$, which includes global vector maps of roads, pathways,

174 railroads, structures, and trails. The vector maps were converted to raster datasets with a $1 \times 1$

$175 \mathrm{~km}$ grid resolution. Some data provided different subtypes of roads (e.g. the information that a

176 route is under construction or its status is unsure). This information was generalized to the

177 classes in Table 1. All routes represented in the datasets allow material transport. The class

178 "Structure" was omitted, because it contained only few datasets. The routes represented in the

179 VMAP0 "pathway" dataset are interpreted as small roads and thus classed as roads. To ensure

180 connectivity within the transport network, a $5 \mathrm{~km}$ buffer around all mapped transport lines is

181 assumed to be usable for transport. Areas without transport routes are considered impassable.

$182 \mathrm{CO}_{2}$ emissions per kilometer vary widely between different modes of transport ${ }^{29}$, even for given 
183 vehicle types with varying load or driving style ${ }^{38}$. The $\mathrm{CO}_{2}$ budget includes upper (pessimistic)

184 and lower (optimistic) ends of the provided $\mathrm{CO}_{2}$ emission ranges per $\mathrm{km}$ and tonne ${ }^{29}$ (Table 1).

185 These values are similar to $\mathrm{CO}_{2}$ efficiency in road freight transportation from other sources ${ }^{39}$.

186 Transport $\mathrm{CO}_{2}$ emissions between source rocks and application areas were calculated as

187 minimum (mean) of a cost distance raster (ESRI ArcGIS functionality) per continuous area of

188 arable land in the optimistic (pessimistic) scenario. The calculations were performed using the

189 "Zonal Statistics" tool implemented in ArcGIS. The optimistic scenario considers the minimum

190 transport emissions per area, following the argument that as soon as the material arrives at the

191 application area, the application emissions cover the transport on the field (possibly an

192 underestimation for large agricultural areas consisting of many fields). The pessimistic scenario

193 considers the mean transport emissions per application area, which certainly overestimates the

194 transport emissions in many cases.

195 Results

196 Globally $736,000 \mathrm{~km}^{2}$ of suitable source rock areas are mapped. Potential application areas for

197 terrestrial enhanced weathering amount to $14,700,000(11,800,000) \mathrm{km}^{2}$ in the optimistic (and

198 pessimistic) scenario (Figure 1). Throughout the text, results for the pessimistic scenario are

199 represented in parentheses.

200 The grains spread on the application areas can potentially sequester up to $1.1(0.8) \mathrm{t} \mathrm{CO}_{2} \mathrm{t}^{-1}\left(\mathrm{t}^{-1}\right.$ 201 means "per tonne of rock") in the optimistic (and pessimistic) scenario. Before transport to the 202 application areas, the source rocks need to be mined (extraction) and their grain size sufficiently 203 reduced (comminution), which emits $0.074(0.229) \mathrm{t} \mathrm{CO}_{2} \mathrm{t}^{-1}$. Spreading the material on the

204 application areas (excluding transport) emits $0.001(0.004) \mathrm{t} \mathrm{CO}_{2} \mathrm{t}^{-1}$. The emissions associated 
205 with these three aspects are spatially static - they do not change with distance between source 206 rock and application areas.

207 Subtraction of the named spatially static emissions leaves $\mathrm{CO}_{2}$ for $17,000(5,000) \mathrm{km}$ transport 208 on road or $140,000(21,000) \mathrm{km}$ on railroad after which the emissions would exceed the potential 209 maximum $\mathrm{CO}_{2}$ sequestration. $89 \%$ of the application areas are connected to the transport 210 network. The transportation $\mathrm{CO}_{2}$ emissions from source to application areas average 0.007 211 (0.022) $\mathrm{t} \mathrm{CO}_{2} \mathrm{t}^{-1}$, which amounts to $0.7 \%(4.0 \%)$ of the potential $\mathrm{CO}_{2}$ sequestration after the 212 emissions of the spatially static parameters. The available $\mathrm{CO}_{2}$ for sequestration (maximum 213 potential $\mathrm{CO}_{2}$ minus emissions, equation 1) differs strongly for both scenarios. Even the 214 maximum transport emissions in the optimistic scenario do not compensate for the difference 215 between the static emissions of the optimistic and pessimistic scenarios. This implies that the 216 smallest available $\mathrm{CO}_{2}$ for sequestration at any application area in the optimistic scenario is 217 higher than the highest available $\mathrm{CO}_{2}$ in the pessimistic scenario (Figure 2). This highlights that 218 transport costs are not a major constraint to the effectiveness of the enhanced weathering 219 technique. In addition, source rock occurrences, which may not be represented in the GLiM units 220 containing ultramafic rocks could shorten transport routes and reduce the average transport 221 emissions at global scale even further. After subtracting all emissions, on average $1.02(0.54) \mathrm{t}$ $222 \mathrm{CO}_{2} \mathrm{t}^{-1}$ are available for sequestration at the application areas in the optimistic (pessimistic) 223 scenario.

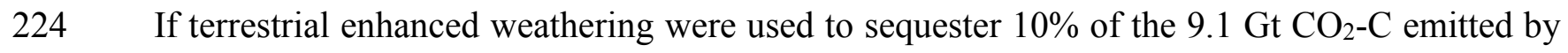
225 fossil fuel combustion and cement production in $2010^{40}, 0.8$ (1.7) Gt of ultramafic rock material 226 would needed to be weathered according to the optimistic (pessimistic) scenario. All this 227 material would need to be mined, crushed and transported to the application regions. For 
228 comparison, the estimated present total mass movement by humans is 40 to $45 \mathrm{Gt} \mathrm{a}^{-1}{ }^{41}$. 229 Certainly, moving these large additional masses would have strong socioeconomic and 230 environmental consequences.

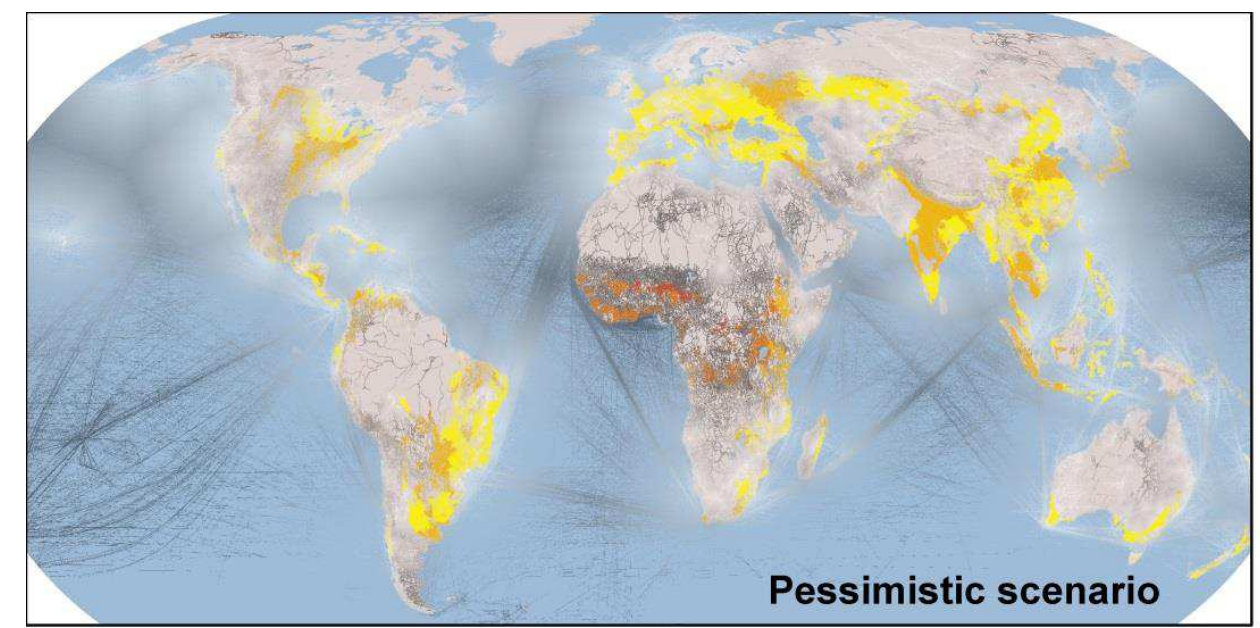

233

234 Figure 2: Available $\mathrm{CO}_{2}$ for sequestration in the application areas. The emissions by transport

235 are shown for comparison. The class "not realized" represents the values between 0.6 and 0.9

236 which do not occur in any of the maps. Everywhere in the optimistic scenario, more $\mathrm{CO}_{2}$ is

237 available for sequestration than anywhere in the pessimistic scenario.
$\mathrm{CO}_{2}$ available for sequestration (t $\mathrm{CO}_{2} \mathrm{t}^{-1}$ rock)

$0.42-0.45$

$0.45-0.5$

$0.5-0.55$

$0.55-0.6$

not realized

$0.9-1$

$1.00-1.01$

$1.01-1.02$

$1.02-1.025$

\section{Transport $\mathrm{CO}_{2}$} emissions $\left(\mathrm{t} \mathrm{CO}_{2}\right)$

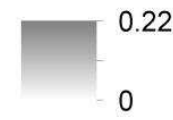

\section{Optimistic scenario}




\section{Discussion}

239 In the optimistic scenario, associated emissions reduce the actual $\mathrm{CO}_{2}$ sequestration only

240 slightly below the potential maximum $\mathrm{CO}_{2}$ sequestration (Figure 3). The pessimistic scenario

241 shows a substantial reduction of the actual $\mathrm{CO}_{2}$ sequestration, mainly because of the assumed

242 less favorable rock composition (and the resulting smaller maximum $\mathrm{CO}_{2}$ consumption) and

243 increased $\mathrm{CO}_{2}$ emissions of comminution (Figure 3). The effect on the difference between the

244 optimistic and pessimistic scenarios is largest for the potential maximum $\mathrm{CO}_{2}$ sequestration. It is

245 responsible for $80.6 \%$ of the variability of the available $\mathrm{CO}_{2}$ for sequestration in a Monte Carlo

246 Simulation (100,000 draws, Oracle Crystal Ball software, assuming a uniform distribution

247 between optimistic and pessimistic values of all parameters). The second most sensitive

248 parameter is comminution, contributing $19.2 \%$ to the variability. Efficiency improvements and

249 renewable energy usage could reduce the associated $\mathrm{CO}_{2}$ emissions below the optimistic scenario

250 assumed here. Uncertainty in comminution requirements is largely down to uncertainty in

251 weathering rates. The slower the weathering rate, the more processing is required to produce the

252 same dissolution per mass. Experimental evidence is needed that examines the dissolution

253 kinetics in various potential application environments. Chemical weathering rate constants (per

254 surface area of rock) have also been shown to increase with finer material as a result of

255 'mechano-chemical activation', but only a small number of studies explore this in silicate

256 minerals and the impact on enhanced weatheringremains unclear ${ }^{8,23,37}$. The emissions of

257 mining, application, and also transport (on average) are negligible for the variability of $\mathrm{CO}_{2}$

258 emissions of terrestrial enhanced weathering $(0,0$, and $0.2 \%$, respectively). The sensitivity

259 analysis suggests that investigations of suitable source rocks, energy requirements of

260 comminution and mineral reactivity in the environment are critical in assessing the potential of

261 terrestrial enhanced weathering. The timeframe of current $\mathrm{CO}_{2}$ policy might even qualify 
262 carbonates as enhanced weathering source rock $^{42}$, which weather faster than ultramafic 263 silicates ${ }^{22}$.

264

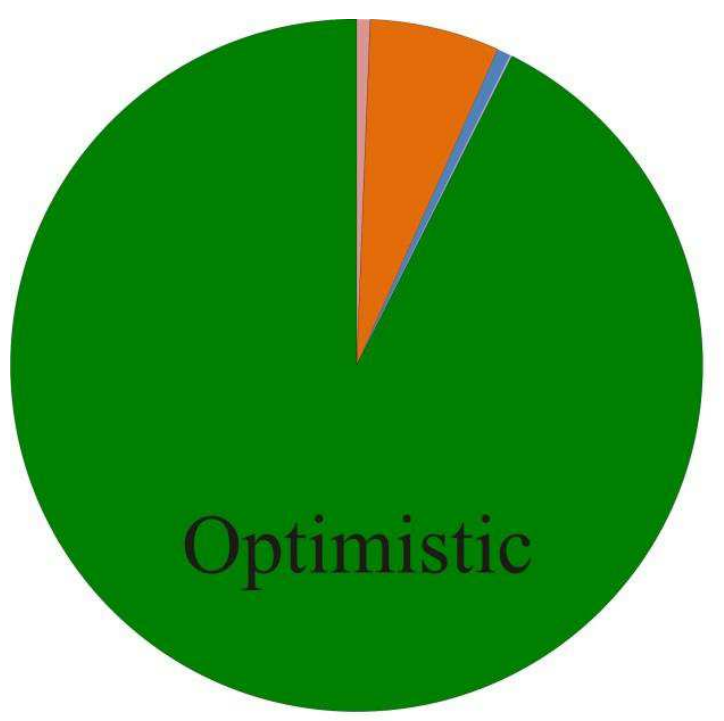

Mining Crushing / milling
Transport

Application

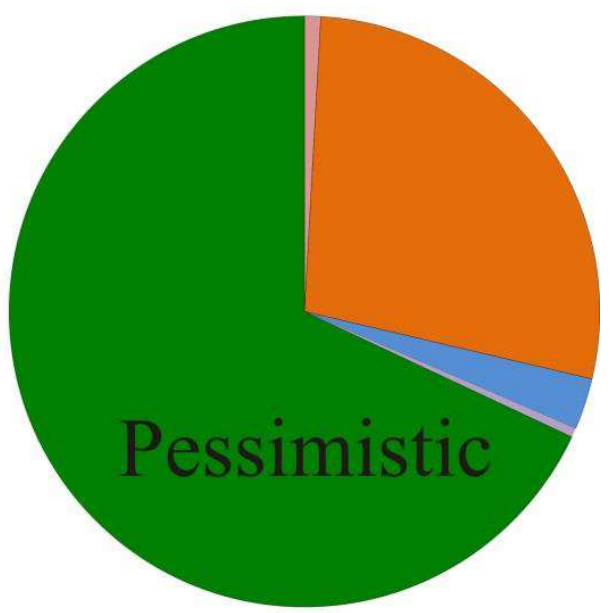

$\mathrm{CO} 2$ sequestration

Figure 3: $\mathrm{CO}_{2}$ budgets per tonne rock material according to the optimistic scenario and

267 pessimistic scenario. The area of the optimistic pie is 1.4 times that of the pessimistic, 268 representing the different potential maximum $\mathrm{CO}_{2}$ sequestration.

270 One specific geological unit, the Semail Opthiolite in Oman, was suggested as location for

271 carbon management by in-situ-carbonation, and its carbon sequestration potential is therefore

272 well researched ${ }^{43}$. To explore its potential for enhanced weathering, and as an example for the

273 effect of transportation, we ran the transport coast routing model with the Semail Opiolite,

274 represented in the Geological map of the Middle East ${ }^{44}$, as single source rock in the GIS (Figure

275 4). Abundantly available Harzburgites from the Samail Ophiolite contain $25 \% \mathrm{Mg}$ by weight ${ }^{45}$,

276 which translate to a potential maximum $\mathrm{CO}_{2}$ sequestration of $0.89 \mathrm{t} \mathrm{CO}_{2} \mathrm{t}^{-1}$. After deducting the 
277 pessimistic scenario emissions, treating the large agricultural areas in Europe and most parts

278 South-East Asia with material of the Samail Ophiolite would still sequester half a tonne $\mathrm{CO}_{2}$ per

279 tonne of rock (Figure 4). Even transport to the Corn Belt in North America would still allow

280 some $\mathrm{CO}_{2}$ sequestration and only in the remotest areas of the Americas the $\mathrm{CO}_{2}$ sequestration is

281 reduced below $0.3 \mathrm{t} \mathrm{CO}_{2} \mathrm{t}^{-1}$ by transport emissions (Figure 4).

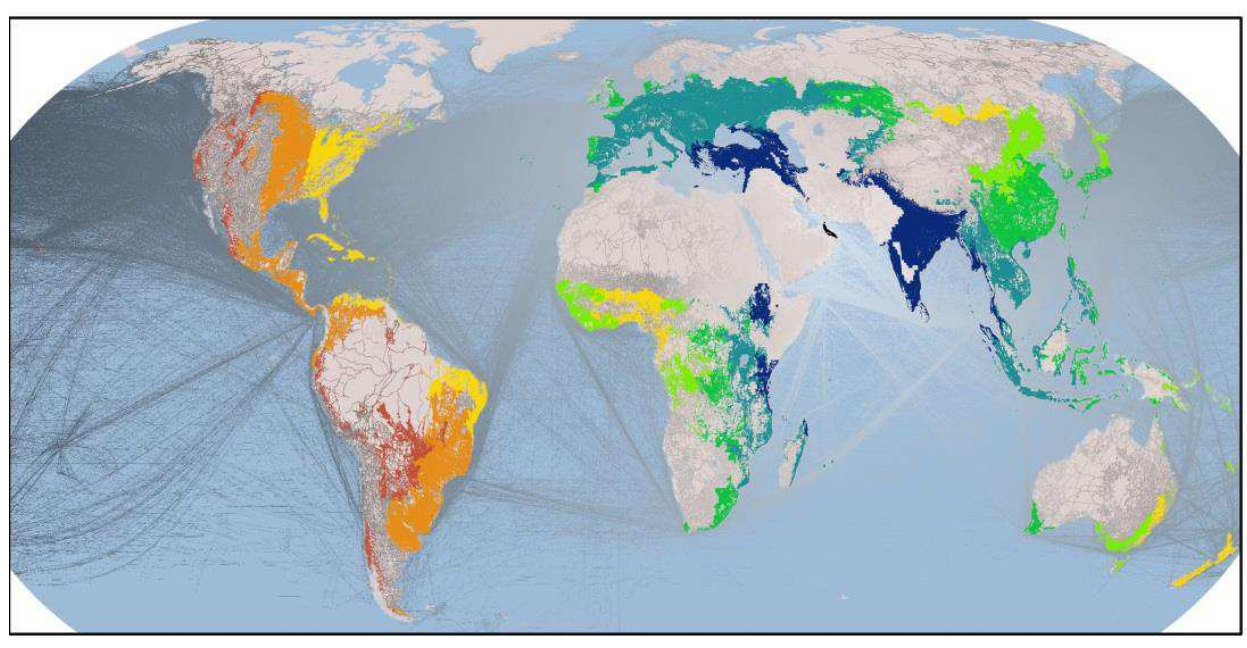

CO2 available for sequestration ( $\mathrm{C} \mathrm{CO}_{2} \mathrm{t}^{-1}$ rock)

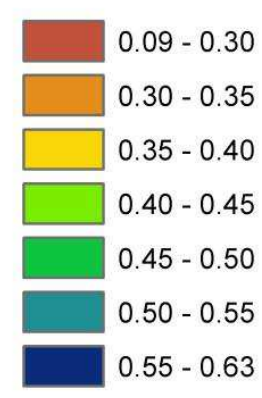

Transport $\mathrm{CO}_{2}$ emissions $\left(\mathrm{t} \mathrm{CO}_{2}\right)$

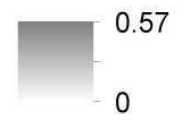

284 Figure 4: Conservative scenario of terrestrial enhanced weathering $\mathrm{CO}_{2}$ sequestration efficiency 285 using the Samail Ophiolite as source rock (marked in black in the map, located in Oman).

286 The logical next step, after identifying the total potential of enhanced weathering is to identify 287 the rates at which the rock flour weathers in application areas and add these rates to the 288 evaluation. Mineral reactivity, and thus weathering rates, depend on a number of environmental 289 parameters ${ }^{7}$. While, chemical weathering rates determined in controlled laboratory experiments, 290 (e.g. far from equilibrium and strongly influenced by temperature ${ }^{46}$ and $\mathrm{pH}^{47}$ ) can be used as an 291 upper estimate, the large difference of rates compared with catchment studies prevents precice 
292 assessment of terrestrial enhanced weathering.. Only dedicated experiments conducted to assess

293 dissolution kinetics in specific conditions could quantify extrinsic environmental impacts (e.g.

294 temperature) on chemical weathering rates in the field ${ }^{19,48}$. Pertinent to this is the influence of

295 plants and microorganisms on chemical weathering (see Manning and Renforth for discussion).

296 A comparison of five catchments in Iceland showed that in the vegetated catchments, chemical

297 weathering was increased between 2 and 10 times depending on vegetation type and mineral ${ }^{49}$.

298 Similarly, a correlation between vegetation type and weathering induced bicarbonate fluxes was

299 shown for 338 stream catchments in North America ${ }^{20}$. Field studies also showed the potential of

300 microorganisms $s^{50}$ and fungi ${ }^{51,52}$ to increase weathering rates, which are nearly ubiquitous in

301 natural environments ${ }^{53}$. The biological increase of chemical weathering rates could allow

302 comminution to larger grain sizes, which would save energy and improve the $\mathrm{CO}_{2}$ budget.

303 However, a lot more research on the controls of potential rates of enhanced weathering is

304 needed, before a qualified quantification of the temporal dimension of this technique will be

305 feasible.

306 In addition, enhanced weathering was reported to improve soil and plant productivity in 307 agriculture. One widely applied method of enhanced weathering of carbonate rocks is 308 agricultural liming to raise $\mathrm{pH}$ values of acidic soils, which already significantly impacts e.g. 309 alkalinity flux into the Gulf of Mexico ${ }^{54}$. Enhanced weathering of silicate rocks could benefit the 310 primary agricultural use of the areas where it may be applied. The released silicon is a beneficial 311 nutrient for many plants ${ }^{55}$, it enhances resistance of rice to certain diseases ${ }^{56}$ and helps some 312 grasses to defend against herbivores ${ }^{57}$. In addition, trace contents of phosphorus and other 313 elements in the weathering rock powder could increase the productivity of some agricultural $314 \operatorname{areas}^{58}$. Alternatively, metals released by the weathering rock powder could inhibit plant growth 
315 and use ${ }^{10}$. These effects particularly impact the choice of source rocks to optimize the mineral

316 content according to the needs in the application areas. The small proportion of transport

317 emissions to the $\mathrm{CO}_{2}$ budget suggests a choice of source rocks based on their optimal mineral

318 content rather than based on their proximity to the application areas. The effect of enhanced

319 weathering on agricultural output will be one of the main factors determining the success of the

320 method. Thus, not only regarding enhanced weathering as a $\mathrm{CO}_{2}$ removal method but also

321 regarding alternative fertilization methods in the face of dwindling phosphate rock resources ${ }^{59}$,

322 the potential effects of enhanced rock weathering on agricultural productivity ${ }^{60}$ need more

323 research.

324 Regarding the huge logistics necessary for global application, terrestrial enhanced weathering

325 can only be one piece of the puzzle to control or reduce atmospheric $\mathrm{CO}_{2}$ levels. This study

326 highlights that associated emissions not not exceed the carbon sequestration potential for most

327 application areas even under pessimistic assumptions. However, as costs are usually expressed

328 in terms of net carbon sequestration potential (e.g US\$ $\mathrm{tCO}_{2}{ }^{-1}$, or ${\mathrm{GJ} \mathrm{tCO}_{2}}^{-1}$ ) the closer the

329 budget approaches zero, the higher the unit cost. Combining the assumptions of energy use for

330 extraction, comminution and spreading (Table 1), converting the transport emissions into energy

331 requirements (assuming an emissions intensity of $77 \mathrm{gCO}_{2} \mathrm{MJ}^{-1} \mathrm{REF}$ ), and normalizing against

332 net carbon sequestration, the total energy requirements of terrestrial enhanced weathering is 1.6

333 (9.9) GJ per tonne of $\mathrm{CO}_{2}$ sequestered. This range is similar to other technologies that propose to

334 remove carbon dioxide from the atmosphere (e.g. Renforth et al 2013).

335 Terrestrial enhanced weathering could be targeted in regions with high potential weathering 336 rates or on soils depleted in cations and subject to biological carbon management e.g.

337 afforestation, where suitable rocks could provide nutrients for biological carbon storage. Large 
uncertainties in the budget, the weathering rates, and the possible side effects on soil productivity highlight the need for more targeted research before practical application might commence.

\section{Funding Sources}

342 Nils Moosdorf and Jens Hartmann are supported through the German Research Foundation

343 (Cluster of Excellence 'CLiSAP' (EXC177), University of Hamburg, and grant HA 4472/10-1

344 within the priority program SPP 1689/1 “Climate Engineering”), funded through the German

345 Science Foundation (DFG). Phil Renforth is supported by the Oxford Martin School (University 346 of Oxford).

\section{Acknowledgements}

348 This study uses freely available data, whose publishers (e.g. European

349 Chemical Industry Council, U.S. National Imagery and Mapping Agency), are acknowledged.

350 We acknowledge three anonymous reviewers, whose comments added to the value of the 351 manuscript.

\section{References}

354 1. Caldeira, K.; Bala, G.; Cao, L., The Science of Geoengineering. Annual Review of Earth 355 and Planetary Sciences 2013, 41, (1), 231-256.

3562 2. Royal Society, Geoengineering the climate: science, governance and uncertainty. The 357 Royal Society: London, 2009; p 97.

358 3. Vaughan, N. E.; Lenton, T. M., A review of climate geoengineering proposals. Clim. 359 Change 2011, 109, (3-4), 745-790.

360 4. McLaren, D., A comparative global assessment of potential negative emissions 361 technologies. Process Saf Environ 2012, 90, (6), 489-500.

$362 \quad 5 . \quad$ Seifritz, W., Co2 Disposal by Means of Silicates. Nature 1990, 345, (6275), 486-486.

363 6. Schuiling, R. D.; Krijgsman, P., Enhanced weathering: An effective and cheap tool to 364 sequester $\mathrm{CO}_{2}$. Clim. Change 2006, 74, (1-3), 349-354. 
7. Hartmann, J.; West, A. J.; Renforth, P.; Köhler, P.; De La Rocha, C. L.; Wolf-Gladrow, D. A.; Dürr, H. H.; Scheffran, J., Enhanced chemical weathering as a geoengineering strategy to reduce atmospheric carbon dioxide, supply nutrients, and mitigate ocean acidification. Reviews of Geophysics 2013, 51, (2), 113-149.

8. Hangx, S. J. T.; Spiers, C. J., Coastal spreading of olivine to control atmospheric $\mathrm{CO} 2$ concentrations: A critical analysis of viability. Int J Greenh Gas Con 2009, 3, (6), 757-767.

9. Renforth, P., The potential of enhanced weathering in the UK. Int J Greenh Gas Con 2012, 10, 229-243.

10. ten Berge, H. F. M.; van der Meer, H. G.; Steenhuizen, J. W.; Goedhart, P. W.; Knops, P.; Verhagen, J., Olivine Weathering in Soil, and Its Effects on Growth and Nutrient Uptake in Ryegrass (Lolium perenne L.): A Pot Experiment. PLoS ONE 2012, 7, (8), e42098.

11. Berner, R. A.; Lasaga, A. C.; Garrels, R. M., The Carbonate-Silicate Geochemical Cycle and Its Effect on Atmospheric Carbon-Dioxide over the Past 100 Million Years. American Journal of Science 1983, 283, (7), 641-683.

12. Kempe, S., Carbon in the rock cycle. In The Global Carbon Cycle, Bolin, B.; Degens, E. T.; Kempe, S.; Ketner, P., Eds. Scientific Committee On Problems of the Environment (SCOPE): Old Woking, 1979; Vol. 13, pp 343-375.

13. Walker, J. C. G.; Hays, P. B.; Kasting, J. F., A Negative Feedback Mechanism for the Long-Term Stabilization of Earths Surface-Temperature. Journal of Geophysical ResearchOceans and Atmospheres 1981, 86, ( $\mathrm{Nc10}), 9776-9782$.

14. Amiotte-Suchet, P.; Probst, J. L.; Ludwig, W., Worldwide distribution of continental rock lithology: Implications for the atmospheric/soil $\mathrm{CO}_{2}$ uptake by continental weathering and alkalinity river transport to the oceans. Global Biogeochemical Cycles 2003, 17, (2), 1038.

15. Gaillardet, J.; Dupre, B.; Louvat, P.; Allegre, C. J., Global silicate weathering and $\mathrm{CO}_{2}$ consumption rates deduced from the chemistry of large rivers. Chemical Geology 1999, 159, (14), 3-30.

16. Hartmann, J.; Jansen, N.; Dürr, H. H.; Kempe, S.; Köhler, P., Global $\mathrm{CO}_{2}$-consumption by chemical weathering: What is the contribution of highly active weathering regions? Global and Planetary Change 2009, 69, (4), 185-194.

17. Köhler, P.; Hartmann, J.; Wolf-Gladrow, D. A., Geoengineering potential of artificially enhanced silicate weathering of olivine. Proceedings of the National Academy of Sciences of the United States of America 2010, 107, (47), 20228-20233.

18. Alloway, B. J., Heavy metals in soils : trace metals and metalloids in soils and their bioavailability. Springer: New York, 2012.

19. Dessert, C.; Dupre, B.; Gaillardet, J.; Francois, L. M.; Allegre, C. J., Basalt weathering laws and the impact of basalt weathering on the global carbon cycle. Chemical Geology 2003, 202, (3-4), 257-273.

20. Moosdorf, N.; Hartmann, J.; Lauerwald, R.; Hagedorn, B.; Kempe, S., Atmospheric $\mathrm{CO}_{2}$ consumption by chemical weathering in North America. Geochimica Et Cosmochimica Acta 2011, 75, (24), 7829-7854.

21. Schopka, H. H.; Derry, L. A.; Arcilla, C. A., Chemical weathering, river geochemistry and atmospheric carbon fluxes from volcanic and ultramafic regions on Luzon Island, the Philippines. Geochimica et Cosmochimica Acta 2011, 75, (4), 978-1002.

22. Meybeck, M., Global chemical weathering of surficial rocks estimated from river dissolved loads. American Journal of Science 1987, 287, (5), 401-428. 
23. Gerdemann, S. J.; O'Connor, W. K.; Dahlin, D. C.; Penner, L. R.; Rush, H., Ex Situ Aqueous Mineral Carbonation. Environmental Science \& Technology 2007, 41, (7), 2587-2593.

412 24. Gadikota, G.; Matter, J.; Kelemen, P.; Park, A.-h. A., Chemical and morphological 413 changes during olivine carbonation for $\mathrm{CO} 2$ storage in the presence of $\mathrm{NaCl}$ and $\mathrm{NaHCO} 3$. Physical Chemistry Chemical Physics 2014.

25. Chizmeshya, A. V. G.; McKelvy, M. J.; Squires, K.; Carpenter, R. W.; Bearat, H. A Novel Approach to Mineral Carbonation: Enhancing Carbonation While Avoiding Mineral

\section{Pretreatment Process Cost; 2007; p Medium: ED.}

26. Kirchofer, A.; Brandt, A.; Krevor, S.; Prigiobbe, V.; Wilcox, J., Impact of alkalinity sources on the life-cycle energy efficiency of mineral carbonation technologies. Energy \& Environmental Science 2012, 5, (9), 8631-8641.

27. Hartmann, J.; Moosdorf, N., The new global lithological map database GLiM: A representation of rock properties at the Earth surface. Geochemistry Geophysics Geosystems 2012, 13, (12), Q12004.

28. National Imagery and Mapping Agency, Vector Map Level 0 (VMAP0). In National Imagery and Mapping Agency, Ed. Davis Library Reference Electronic Resource, 1997.

29. McKinnon, A.; Piecyk, M. Measuring and Managing $\mathrm{CO}_{2}$ Emissions of European Chemical Transport; CEFIC: Edinburgh, 2010.

30. Economic and Social Research Institute (ESRI), ArcWorld Supplement data distributed on CD-ROM with ArcGIS 9.3. In Economic and Social Research Institute (ESRI): Redlands, CA, 2008.

31. Halpern, B. S.; Walbridge, S.; Selkoe, K. A.; Kappel, C. V.; Micheli, F.; D'Agrosa, C.; Bruno, J. F.; Casey, K. S.; Ebert, C.; Fox, H. E.; Fujita, R.; Heinemann, D.; Lenihan, H. S.; Madin, E. M. P.; Perry, M. T.; Selig, E. R.; Spalding, M.; Steneck, R.; Watson, R., A global map of human impact on marine ecosystems. Science 2008, 319, (5865), 948-952.

32. Fröba, N.; Funk, M. Dieselkraftstoffbedarf bei landwirtschaftlichen Arbeiten; Kuratorium for Technik und Bauwesen in der Landwirtschaft e.V. (KTBL): Darmstadt, 2005; p 32.

33. Arino, O.; Gross, D.; Ranera, F.; Bourg, L.; Leroy, M.; Bicheron, P.; Latham, J.; Di Gregorio, A.; Brockman, C.; Witt, R.; Defourny, P.; Vancutsem, C.; Herold, M.; Sambale, J.; Achard, F.; Durieux, L.; Plummer, S.; Weber, J.-L., GlobCover: ESA service for global land cover from MERIS. In Proceedings of the International Geoscience and Remote Sensing Symposium (IGARSS) 2007, IEEE International: Barcelona, 2007; pp 2412 - 2415.

34. Kottek, M.; Grieser, J.; Beck, C.; Rudolf, B.; Rubel, F., World map of the Köppen-Geiger climate classification updated. Meteorologische Zeitschrift 2006, 15, (3), 259-263.

35. Hartmann, J.; Kempe, S., What is the maximum potential for $\mathrm{CO}_{2}$ sequestration by "stimulated" weathering on the global scale? Naturwissenschaften 2008, 95, (12), 1159-1164.

36. Hartmann, J.; Moosdorf, N.; Lauerwald, R.; West, A. J.; Hinderer, M., Global chemical weathering and associated P-release - the role of lithology, temperature and soil properties. Chemical Geology 2014, 363, 145-163.

37. Balaz, P.; Turianicova, E.; Fabian, M.; Kleiv, R. A.; Briancin, J.; Obut, A., Structural changes in olivine $(\mathrm{Mg}, \mathrm{Fe})(2) \mathrm{SiO} 4$ mechanically activated in high-energy mills. Int J Miner Process 2008, 88, (1-2), 1-6.

38. McKinnon, A. C.; Piecyk, M. I., Measurement of $\mathrm{CO} 2$ emissions from road freight transport: A review of UK experience. Energy Policy 2009, 37, (10), 3733-3742.

39. Leonardi, J.; Baumgartner, M., CO2 efficiency in road freight transportation: Status quo, measures and potential. Transport Res D-Tr E 2004, 9, (6), 451-464. 
40. Peters, G. P.; Marland, G.; Le Quere, C.; Boden, T.; Canadell, J. G.; Raupach, M. R., CORRESPONDENCE: Rapid growth in CO2 emissions after the 2008-2009 global financial crisis. Nat Clim Change 2012, 2, (1), 2-4. 41. Hooke, R. L., On the efficacy of humans as geomorphic agents. GSA Today 1994, 4, (9), $217,224,225$.

42. Rau, G. H.; Knauss, K. G.; Langer, W. H.; Caldeira, K., Reducing energy-related CO2 emissions using accelerated weathering of limestone. Energy 2007, 32, (8), 1471-1477. 43. Kelemen, P. B.; Matter, J., In situ carbonation of peridotite for $\mathrm{CO} 2$ storage. Proceedings of the National Academy of Sciences of the United States of America 2008, 105, (45), 1729517300 . 44. Haghipour, A.; Saidi, A., International geological map of the Middle East, second edition, 1:5,000,000 In Commission for the Geological World Map: 2010.

45. Hanghoj, K.; Kelemen, P. B.; Hassler, D.; Godard, M., Composition and Genesis of Depleted Mantle Peridotites from the Wadi Tayin Massif, Oman Ophiolite; Major and Trace Element Geochemistry, and Os Isotope and PGE Systematics. Journal of Petrology 2010, 51, (12), 201-227.

46. Brady, P. V.; Carroll, S. A., Direct effects of $\mathrm{CO}_{2}$ and temperature on silicate weathering - possible implications for climate control. Geochimica et Cosmochimica Acta 1994, 58, (7), 1853-1856.

47. Rozalen, M.; Huertas, F. J.; Brady, P. V., Experimental study of the effect of pH and temperature on the kinetics of montmorillonite dissolution. Geochimica et Cosmochimica Acta 2009, 73, (13), 3752-3766.

48. Riebe, C. S.; Kirchner, J. W.; Finkel, R. C., Erosional and climatic effects on long-term chemical weathering rates in granitic landscapes spanning diverse climate regimes. Earth and Planetary Science Letters 2004, 224, (3-4), 547-562.

49. Moulton, K. L.; West, J.; Berner, R. A., Solute flux and mineral mass balance approaches to the quantification of plant effects on silicate weathering. American Journal of Science 2000, $300,(7), 539-570$.

50. Rogers, J. R.; Bennett, P. C., Mineral stimulation of subsurface microorganisms: release of limiting nutrients from silicates. Chemical Geology 2004, 203, (1-2), 91-108.

51. Hoffland, E.; Kuyper, T. W.; Wallander, H.; Plassard, C.; Gorbushina, A. A.; Haselwandter, K.; Holmstrom, S.; Landeweert, R.; Lundstrom, U. S.; Rosling, A.; Sen, R.; Smits, M. M.; van Hees, P. A.; van Breemen, N., The role of fungi in weathering. Frontiers in Ecology and the Environment 2004, 2, (5), 258-264.

52. $\quad$ Leake, J. R.; Duran, A. L.; Hardy, K. E.; Johnson, I.; Beerling, D. J.; Banwart, S. A.; Smits, M. M., Biological weathering in soil: the role of symbiotic root-associated fungi biosensing minerals and directing photosynthate-energy into grain-scale mineral weathering. Mineralogical Magazine 2008, 72, (1), 85-89.

53. Gorbushina, A. A., Life on the rocks. Environ Microbiol 2007, 9, (7), 1613-1631.

54. Raymond, P. A.; Oh, N. H.; Turner, R. E.; Broussard, W., Anthropogenically enhanced fluxes of water and carbon from the Mississippi River. Nature 2008, 451, (7177), 449-452.

55. Epstein, E., The anomaly of silicon in plant biology. Proceedings of the National Academy of Sciences of the United States of America 1994, 91, (1), 11-17.
56. Datnoff, L. E.; Raid, R. N.; Snyder, G. H.; Jones, D. B., Effect of Calcium Silicate on Blast and Brown Spot Intensities and Yields of Rice. Plant Dis 1991, 75, (7), 729-732. 
501 57. Massey, F. P.; Ennos, A. R.; Hartley, S. E., Herbivore specific induction of silica-based 502 plant defences. Oecologia 2007, 152, (4), 677-683.

503 58. Van Straaten, P., Farming with rocks and minerals: challenges and opportunities. An 504 Acad Bras Cienc 2006, 78, (4), 731-747.

505 59. Cordell, D.; Drangert, J. O.; White, S., The story of phosphorus: Global food security and 506 food for thought. Global Environ Chang 2009, 19, (2), 292-305.

507 60. van Straaten, P., Rocks for Crops: agrominerals of sub-Saharan Africa. ICRAF: Nairobi, $508 \quad 2002 ;$ p 338. 